\title{
Journal of Emergency Primary Health Care
} www.jephc.com

ISSN 1447-4999

\section{EDUCATION}

\section{Enhancing an undergraduate Paramedic degree through the introduction of a health fact sheet assessment task}

\author{
Dr. Deanne H Hryciw \\ Senior Lecturer, School of Biomedical and Health Sciences \\ Victoria University \\ St Albans, VIC 3021 \\ Australia
}

\begin{abstract}
Aims

A component of the Council of Ambulance Authorities Inc. (Australia) guidelines is to facilitate the development of University degree courses which focus on the development of professional behaviour by incorporating educational programs that provide paramedic graduates with workplace skills that will be required for their future careers.
\end{abstract}

\section{Methods}

A health fact sheet assessment task was introduced to first year Bachelor of Health Sciences (Paramedic) students as a part of their curriculum in bioscience. The aims of the assessment task were to improve their understanding of basic anatomy and physiology, and to enhance essential workplace skills such as communicating scientific concepts to members of the general public (lay people). In addition to the task, a survey was distributed to determine the opinion of the students on the health fact sheet assessment task.

\section{Results}

The 166 students who completed the task achieved a high mean grade of 8.16 out of 10 ( \pm 0.77). Fifty-two students completed the survey $(31.32 \%)$, with most students strongly believing that learning to communicate more effectively to the general public was a useful skill and that the health fact sheet assessment task achieved this aim.

\section{Conclusion}

The health fact sheet assessment task was a valuable tool in an undergraduate paramedic curriculum, reinforcing skills that are relevant to an allied health career.

Keywords: curriculum; health fact sheet; survey; undergraduate paramedic programs 


\section{Introduction}

In 2007, The Council of Ambulance Authorities Inc. (CAA) published guidelines for the assessment and accreditation of University Paramedic Programs in Australia and New Zealand. ${ }^{1}$ One component of the guidelines is the recommendation for University paramedic degree courses to incorporate educational programs in the curriculum that will foster the development of professional behaviour and workplace skills that will be required of paramedic graduates in their future careers. ${ }^{1}$

In 1999, Victoria University introduced a Bachelor of Health Sciences (Paramedic) degree to educate students in the skills required for Paramedicine. The university aims to produce students that:

1. have attained the skills, knowledge and personal attributes necessary to apply for selection and promotion in paramedicine pathways;

2. have well established clinical decision making and problem solving abilities;

3. are able to communicate effectively with others; and,

4. can work either individually or in a team environment.

As part of the Bachelor of Health Sciences (Paramedic) degree, students undertake two semesters of Bioscience (Anatomy and Physiology) in their first year. Often students find the topics in anatomy and physiology difficult, which is not uncommon among mature age students who are returning to education after some time, or who may have had to limited exposure to biology in their high school education.

Research suggests that students learn more effectively if the knowledge and skills they acquire are inserted and contextualized in relevant real-life situations. ${ }^{2}$ This was validated in a study by Cliff and Wright, using the analysis of disease states to help students increase and solidify their understanding of physiological facts, concepts, and principles. ${ }^{3}$ Further research also suggests that written communication using everyday language is an efficient method for reinforcing key concepts and ideas. ${ }^{4}$

As science is often jargon based, lay people can have difficulty understanding complex scientific principles. Not only does this barrier create gaps in knowledge acquisition, it prevents effective communication. However, if improvements to the expression of scientific concepts are taught to students in everyday language, it is probable that students will develop a deeper understanding about a topic of interest, while improving their ability to communicate complex scientific principles to others in everyday language. ${ }^{5}$

Based on this previous research, an assessment task was developed to emphasize the main concepts of physiology, as well as improve the learning experience of students in the first year of the Bachelor of Health Sciences (Paramedic) degree. The aim of the task was to enhance the students' understanding of anatomy and physiology, while developing skills, such as effective scientific communication ${ }^{6}$ which are beneficial in paramedic practice.

\section{Methods}

This project was granted human ethics approval from the Faculty of Health, 
Engineering and Science Human Research Ethics Committee, Victoria University (HRETH 08/221).

Students enrolled in second semester Bioscience 2 RBM1211 completed the health fact sheet assessment task which comprised a short (one page in length, front and back) assignment that was used to provide basic knowledge on one of four potential topics: Leukaemia, Gestational Diabetes, Coeliac Disease and Cystic Fibrosis. The topics were chosen to reinforce the basic components of physiology associated with blood, pregnancy, digestive system and respiratory system, which the students were also studying at the time.

To complete the task requirements as shown in Figure 1, students were encouraged to use everyday language that was understandable to members of the general public. ${ }^{4}$

The Health Fact Sheet assignment submissions (10\% of the total course) were marked using a criteria-based assessment rubric (Figure 2), which afforded specific feedback according to four criteria:

1. Facts (the key facts and concepts being determined by the faculty member before the assignment was graded)

2. Breadth and depth of information provided (was enough information provided?)

3. Presentation (use of language, ease of reading)

4. Quality of writing and use of resources

In addition, an opinion survey adapted from Moni et al. ${ }^{7}$ was administered to students after they completed the Health Fact Sheet Assignment (Appendix 1). The aim of the survey was to determine the usefulness of the health fact sheet assessment task, and its perceived relevance to the students' paramedic careers.

The survey consisted of ten closed questions using a Likert rating scale from 1 to 6 (see Appendix 1). To improve the validity of the survey, a mix of questions which were worded affirmatively or negatively were used. For example: Question 2 - I did NOT understand the instructions for the heath fact sheet and Question 10 - The instructions for this task were clear.

\section{Results}

The mean age of students enrolled was 24 years ( \pm 6 years) with $54 \%$ of students female. Of the 166 students enrolled in RBM1211 in semester 2, 2008, all completed the assessment task. The mean grade for the health fact sheet was 8.16 out of 10 (with $\mathrm{SD}$ of 0.77). The overall mean grade for the Bioscience 2 RBM1211 course was 68.6 out of 100 (with SD of 10.6).

Fifty-two student opinion surveys $(31.32 \%)$ were returned. Sixty percent of students that completed the survey were females. No students identified themselves as using English as a second language. No surveys were deemed invalid (all responses marked as "3."). The mean, median and interquartile range from student responses from closed survey questions are shown in Figure 3. 
The opinion survey indicated that most students believed that the Health Fact Sheet assessment task was useful, and focused on the development of workplace skills. In general, students disagreed that the task was boring (median $=2, P<0.0001$ ) and not useful for their future careers (median $=2, P<0.0001$ ). In addition, students strongly supported the inclusion of this piece of assessment in place of a "lab report" (median $=1, P<0.0001$ ). Importantly, most students reported strongly that paramedics must be able to communicate (median $=6, P<0.0001$ ), which emphasizes the goals of this degree. In addition, most students reported that they believed that the health fact sheet assessment task helped to develop their communication skills (median $=4, P<$ 0.0001 ). Most students agreed that the task was valuable (median $=4, P<0.0001$ ).

\section{Discussion}

These findings demonstrate that the health fact sheet assessment task is a useful tool in biomedical education as it develops students' understanding of key physiological content. Importantly, as effective scientific communication to lay people is an essential workplace skill requirement for paramedics, the use of everyday language in this assessment task develops the scientific literacy that is required of students enrolled in an undergraduate paramedic course.

Previous studies have noted that mature age students gain the greatest degree of satisfaction by utilising their social and academic skills. ${ }^{8}$ As one of the assets of mature age students is their prior knowledge and life experience, ${ }^{9}$ successful transition for these students should incorporate teaching and learning strategies that build upon these skills.

With respect to the health fact sheet assessment task, a number of students expressed that they had personal experiences, or a family history of a particular disease. This potentially enriched the learning experience for students in this category as their understanding of the disease topic was conceptualized through prior knowledge, reinforced through the assessment task and communicated in everyday language to others. Students in this category also appeared to view the learning experience much more favourably.

Allied health workers are required to develop skills which will enable them to provide sound scientific communication to members of the general public. However limited educational tools have been developed to specifically focus on this skill in undergraduate degree programs. In future iterations of this study, it would be important to determine if the assessment task achieved this aim, potentially by surveying members of the community based on similar survey methods previously published. ${ }^{7}$ This would further demonstrate the usefulness of the health fact sheet assessment task, through its ability to educate members of the general public in important areas of science and disease.

\section{Conclusion}

In conclusion, a health fact sheet assessment task is a valuable teaching and learning tool that enhanced the first year experience of the Bachelor of Health Science (Paramedic) students enrolled in a bioscience unit and provided them with an opportunity to cement their anatomy and physiology knowledge as well as develop basic health communication skills that are important in their future paramedic careers. 


\section{References}

1. Walker J. Guidelines for the assessment and accreditation of university paramedic programs. (Version 2.0). Council of Ambulance Authorities Inc: Adelaide, South Australia; 2007.

2. Sé AB, Passos RM, Ono AH, Hermes-Lima M. The use of multiple tools for teaching medical biochemistry. Advances in Physiological Education. 2008; 32:38-46.

3. Cliff WH, Wright AW. Directed case study method for teaching human anatomy and physiology. Advances in Physiological Education. 1996;270: 1928.

4. Fellows NJ. A window into thinking: using student writing to understand conceptual change in science learning. Journal of Research in science teaching 1994;31:985-1001.

5. Bruno F, Vercellesi L. Science information in the media: An academic approach to improve its intrinsic quality. Pharmacological Research. 2002;45(1):51-55.

6. Koehler KE, Hawley RS. Tales from the front lines: the creative essay as a tool for teaching genetics. Genetics. 1999;152:1229-40.

7. Moni RW, Hryciw DH, Poronnik P, Moni KB. Using explicit teaching to improve how bioscience students write to the lay public. Advances in Physiological Education. 2007;31:167-75.

8. Kantanis T. Same or different: issues that affect mature age undergraduate students' transition to university. In: Sixth Pacific Rim First-Year in Higher Education Conference 2002; Christchurch, New Zealand, Monash University, 2002. p. 1-10.

9. Boelen M, Kenny A. Supporting enrolled nurse conversion - The impact of a compulsory bridging program. Nurse Education Today. 2009;533-537.

\section{Acknowledgements}

The author thanks the students who gave their time to participate in the study.

This Article was peer reviewed for the Journal of Emergency Primary Health Care Vol.7, Issue 3, 2009 
Figure 1: Task requirements for Health Fact Sheet assessment task

\section{RBM1211 Semester 2 Assignment: Health Fact Sheet}

Please follow the instructions carefully

You are required to submit a health fact sheet on ONE of the topics below.

Topics

1. Cystic Fibrosis

2. Leukaemia

3. Coeliac disease

4. Gestational Diabetes

\section{Instructions for the fact sheet}

1. The fact sheet must be 1 page in length

2. The fact sheet must have a clear title indicating the disease and topic to be covered

3. The fact sheet must contain relevant information e.g. Describe the disease (including basic physiology) What are the symptoms? Risk factors? How does one get diagnosed? Resources (further information)?

4. The fact sheet must be visually pleasing

5. The fact sheet should used basic language and be understandable to average members of the public 
Figure 2: Assessment rubric for Health Fact sheet assessment task

RBM1211 Criteria Sheet: Health Fact Sheet (10\%)

\begin{tabular}{|c|c|c|c|c|}
\hline & & & & Grade \\
\hline FACTS & $\begin{array}{ll}\text { High quality } \\
\text { information } \\
\text { was } \\
\text { appropriately } \\
\text { recorded and } \\
\text { presented } \\
\text { Physiological } \\
\text { content is clear }\end{array}$ & $\begin{array}{l}\text { Information } \\
\text { was } \\
\text { appropriately } \\
\text { recorded and } \\
\text { presented } \\
\text { - Limited } \\
\text { physiological } \\
\text { content }\end{array}$ & $\begin{array}{l}\text { Poor quality } \\
\text { information } \\
\text { was recorded } \\
\text { and presented } \\
\text { No } \\
\text { physiological } \\
\text { content }\end{array}$ & 14 \\
\hline COVERAGE & $\begin{array}{l}\text { Thorough and } \\
\text { cohesive } \\
\text { coverage of } \\
\text { topic }\end{array}$ & $\begin{array}{l}\text { Limited } \\
\text { coverage of } \\
\text { topic }\end{array}$ & $\begin{array}{l}\text { - No coverage } \\
\text { of topic }\end{array}$ & 14 \\
\hline PRESENTATION & $\begin{array}{ll} & \text { Visually } \\
\text { pleasing } \\
\text { presentation }\end{array}$ & $\begin{array}{ll}\text { - } & \text { Standard } \\
\text { presentation }\end{array}$ & $\begin{array}{l}\text { - Poor quality } \\
\text { presentation }\end{array}$ & $/ 1$ \\
\hline $\begin{array}{l}\text { QUALITY } \\
\text { of WRITING and } \\
\text { RESOURCES }\end{array}$ & $\begin{array}{l}\text { Grammar, } \\
\text { syntax and } \\
\text { spelling are of } \\
\text { a publishable } \\
\text { (professional) } \\
\text { standard } \\
\text { throughout } \\
\text { Resources are } \\
\text { clearly } \\
\text { indicated } \\
\end{array}$ & $\begin{array}{l}\text { Grammar, } \\
\text { syntax and } \\
\text { spelling are of } \\
\text { a sound } \\
\text { standard } \\
\text { - Limited } \\
\text { resources are } \\
\text { clearly } \\
\text { indicated }\end{array}$ & $\begin{array}{l}\text { Grammar, } \\
\text { syntax and } \\
\text { spelling are } \\
\text { of a an } \\
\text { unacceptable } \\
\text { standard } \\
\text { No resources } \\
\text { indicated }\end{array}$ & $/ 1$ \\
\hline
\end{tabular}

Final grade: 
Figure 3: Student responses [median \pm interquartile ranges (IQR)] to items an opinion survey (see Appendix 1)

\begin{tabular}{|l|l|l|l|}
\hline Question & Mean & Median & $\begin{array}{l}\text { Interquartile } \\
\text { Range }\end{array}$ \\
\hline $\mathbf{1}$ & 3.3 & 3 & 1 \\
\hline $\mathbf{2}$ & 1.47 & $1^{*}$ & 1 \\
\hline $\mathbf{3}$ & 4.09 & $4^{*}$ & 2 \\
\hline $\mathbf{4}$ & 1.64 & $1^{*}$ & 1 \\
\hline $\mathbf{5}$ & 4.3 & $4^{*}$ & 1 \\
\hline $\mathbf{6}$ & 2.34 & $2^{*}$ & 1 \\
\hline $\mathbf{7}$ & 2.2 & $2^{*}$ & 1 \\
\hline $\mathbf{8}$ & 2.7 & 3 & 2 \\
\hline $\mathbf{9}$ & 5.83 & $6^{*}$ & 0 \\
\hline $\mathbf{1 0}$ & 5.13 & $5^{*}$ & 1 \\
\hline
\end{tabular}

$* P<0.05(n=52)$ based on the difference in median values from the scale point of 3 (neither disagree nor agree) using the nonparametric Wilcoxon signed-rank test. Questions are in Appendix 1. 


\section{Appendix 1: Questionnaire (adapted from Moni et al. 2001) ${ }^{7}$}

RBM1211: $\quad$ Your ideas about the Health Fact Sheet assessment

This survey is for research purposes, is anonymous and completion is voluntary. By completing this survey, you are agreeing that this information can be used for publication.

Sex $\quad M / F \quad$ English as a second language $\quad \mathrm{Y} / \mathrm{N}$

PLEASE READ CAREFULLY and circle ONE number from 1-6

\begin{tabular}{|c|c|c|c|c|c|c|}
\hline & $\begin{array}{c}\text { VERY } \\
\text { STRONGLY } \\
\text { DISAGREE } \\
\end{array}$ & $\begin{array}{l}\text { STRONGLY } \\
\text { DISAGREE }\end{array}$ & $\begin{array}{c}\text { NEITHER } \\
\text { DISAGREE } \\
\text { OR AGREE } \\
\end{array}$ & AGREE & $\begin{array}{c}\text { STRONGLY } \\
\text { AGREE }\end{array}$ & $\begin{array}{c}\text { VERY } \\
\text { STRONGLY } \\
\text { AGREE } \\
\end{array}$ \\
\hline $\begin{array}{l}\text { 1. After completing the } \\
\text { health fact sheet, I } \\
\text { believe that my ability } \\
\text { to communicate has } \\
\text { improved. }\end{array}$ & 1 & 2 & 3 & 4 & 5 & 6 \\
\hline $\begin{array}{l}\text { 2. I did not understand the } \\
\text { instructions for the } \\
\text { health fact sheet. }\end{array}$ & 1 & 2 & 3 & 4 & 5 & 6 \\
\hline $\begin{array}{l}\text { 3. This exercise provided } \\
\text { me with a valuable } \\
\text { learning experience. }\end{array}$ & 1 & 2 & 3 & 4 & 5 & 6 \\
\hline $\begin{array}{l}\text { 4. I would have preferred } \\
\text { to do a written lab } \\
\text { report for assessment. }\end{array}$ & 1 & 2 & 3 & 4 & 5 & 6 \\
\hline $\begin{array}{l}\text { 5. I understood the } \\
\text { usefulness of this task. }\end{array}$ & 1 & 2 & 3 & 4 & 5 & 6 \\
\hline 6. I found this task boring. & 1 & 2 & 3 & 4 & 5 & 6 \\
\hline $\begin{array}{l}\text { 7. I did NOT think that } \\
\text { completing this task } \\
\text { was useful for my future } \\
\text { career. }\end{array}$ & 1 & 2 & 3 & 4 & 5 & 6 \\
\hline $\begin{array}{l}\text { 8. To complete this task, I } \\
\text { consulted with many } \\
\text { other students. }\end{array}$ & 1 & 2 & 3 & 4 & 5 & 6 \\
\hline $\begin{array}{l}\text { 9. I believe it is important } \\
\text { for paramedics to be } \\
\text { able to communicate to } \\
\text { the public. }\end{array}$ & 1 & 2 & 3 & 4 & 5 & 6 \\
\hline $\begin{array}{l}\text { 10. The instructions for this } \\
\text { task were clear. }\end{array}$ & 1 & 2 & 3 & 4 & 5 & 6 \\
\hline
\end{tabular}

